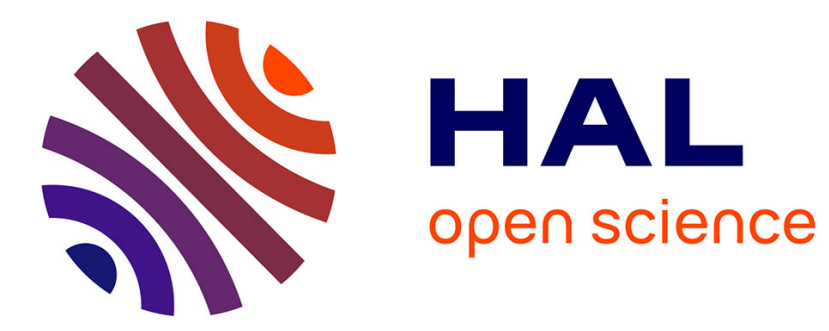

\title{
The Resilience of the Indian Economy to Rising Oil Prices as a Validation Test for a Global Energy-Environment-Economy CGE Model Céline Guivarch, Stéphane Hallegatte, Renaud Crassous
}

\section{- To cite this version:}

Céline Guivarch, Stéphane Hallegatte, Renaud Crassous. The Resilience of the Indian Economy to Rising Oil Prices as a Validation Test for a Global Energy-Environment-Economy CGE Model. 2008. hal-00866431

\author{
HAL Id: hal-00866431 \\ https://hal.science/hal-00866431
}

Preprint submitted on 30 Sep 2013

HAL is a multi-disciplinary open access archive for the deposit and dissemination of scientific research documents, whether they are published or not. The documents may come from teaching and research institutions in France or abroad, or from public or private research centers.
L'archive ouverte pluridisciplinaire HAL, est destinée au dépôt et à la diffusion de documents scientifiques de niveau recherche, publiés ou non, émanant des établissements d'enseignement et de recherche français ou étrangers, des laboratoires publics ou privés. 


\section{DOCUMENTS DE TRAVAIL / WORKING PAPERS}

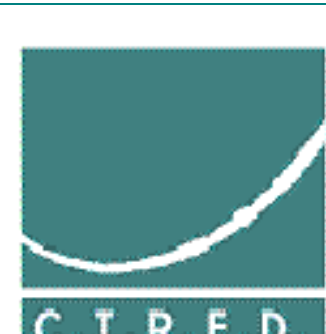

C.I.R.E.D.

No 11-2008

The Resilience of the Indian Economy to Rising

Oil Prices as a Validation Test for a Global Energy-Environment-Economy CGE Model

Céline Guivarch

Stéphane Hallegatte

Renaud Crassous

SEPTEMBRE 2008

\section{C.I.R.E.D.}

Centre International de Recherches sur l'Environnement et le Développement UMR 8568 CNRS / EHESS / ENPC / ENGREF

/ CIRAD / METEO FRANCE

45 bis, avenue de la Belle Gabrielle

F-94736 Nogent sur Marne CEDEX

Tel : (33) 143947373 / Fax : (33) 143947370 
Résumé:

Dans cet article on propose de tester le modèle global hybride d'équilibre général calculable IMACLIM-R en regard des données macroéconomiques. Pour ce faire, on compare les réponses modélisées et observées de l'économie indienne à la montée des prix pétroliers durant la période 2003-2006. Avec un double objectif : d’abord démêler la diversité des mécanismes et politiques à l'œuvre dans la réponse de l'économie de l'Inde à la montée des prix du pétrole, et ensuite valider notre modèle comme un outil capable de reproduire les données statistiques dans le court terme. Avec un paramétrage par défaut, le modèle prédit une diminution significative du taux de la croissance indienne qui n’est pas observée. Cependant l'écart est corrigé par l'introduction de trois mécanismes additionnels identifiés par le Fonds Monétaire International, à savoir la montée des exportations des produits du raffinage pétrolier, le déséquilibre de la balance commerciale permis par un large afflux de capitaux, et le report incomplet de la hausse des prix pétroliers vers les consommateurs indiens. Cet exercice est une première étape pour la validation du modèle, et procure d'intéressants aperçus sur la méthode de modélisation pertinente pour représenter la réponse de l'économie à un choc, aussi bien que sur la façon dont les mécanismes de court terme - et l'action politique peuvent adoucir les impacts négatifs de chocs par les prix de l'énergie ou les politiques climatiques.

Mots-clés: Modèle global d'équilibre général calculable, choc pétrolier, validation de modèle. 


\title{
The Resilience of the Indian Economy to Rising Oil Prices as a Validation Test for a Global Energy-Environment-Economy CGE Model
}

\author{
Céline Guivarch $^{\mathrm{a}, *}$, Stéphane Hallegatte ${ }^{\mathrm{a}, \mathrm{b}}$, Renaud Crassous ${ }^{\mathrm{a}}$ \\ a Centre International de Recherche sur l'Environnement et le Développement, Nogent-sur-Marne, France \\ b Ecole Nationale de la Météorologie, Météo-France, Toulouse, France \\ * Corresponding author at: CIRED, 45bis, Av. de la Belle Gabrielle, F-94736 Nogent-sur-Marne, France. \\ Tel.: +3314394 73 86; fax: +33143947370. \\ E-mail address: guivarch@centre-cired.fr (C. Guivarch).
}

September 2008

\begin{abstract}
This paper proposes to test the global hybrid computable general equilibrium model IMACLIM-R against macroeconomic data. To do so, it compares the modeled and observed responses of the Indian economy to the rise of oil price during the 2003-2006 period. The objective is twofold: first, to disentangle the various mechanisms and policies at play in India's economy response to rising oil prices and, second, to validate our model as a tool capable of reproducing short-run statistical data. With default parametrization, the model predicts a significant decrease in the Indian growth rate that is not observed. However, this discrepancy is corrected if three additional mechanisms identified by the International Monetary Fund are introduced, namely the rise in exports of refined oil products, the imbalance of the trade balance allowed by large capital inflows, and the incomplete passthrough of the oil price increase to Indian customers. This work is a first step toward model validation, and provides interesting insights on the modeling methodology relevant to represent an economy's response to a shock, as well as on how short-term mechanisms - and policy action - can smooth the negative impacts of energy price shocks or climate policies.
\end{abstract}

Keywords: Global CGE model, Oil shock, Model validation. 


\section{Introduction}

In the five decades since Johansen's model of Norway, computable general equilibrium models (CGE) have become influential tools for both research and policy analysis. In more recent years, the twin challenges of energy security and climate change have driven intense modeling efforts, which led in particular to the development of hybrid CGE models (e.g., Bataille et al., 2006, Bosetti et al., 2006, Edenhofer et al., 2006, Schäfer and Jacoby, 2006). These models aim at providing a consistent framework to represent the interactions between macroeconomic mechanisms and the energy sector (Hourcade et al., 2006) and became widespread to make long-term projections of energy-environment-economy (E3) scenarios. The IMACLIM-R model (Sassi et al., 2007), developed in CIRED, counts among these hybrid CGE models. It is a global model with 12 regions and 12 sectors, its architecture is based on a recursive general equilibrium model with sectoral technico-economic modules inserted. A detailed description of the model's architecture is given in Crassous et al. (2006a, 2006b).

As with any model, a key question is its validation and the determination of its validity domain. It appears all the more important as some serious questions have been raised about the empirical validity of CGE models (the econometric critique, e.g. McKitrick, 1998). In particular they are criticized for relying on one year's data to project decades in the future and for not modeling observations (Barker, 2004 and Scrieciu, 2007). The usual explanation for the discrepancy between CGE models projections and observations is that these models are designed to explore long-term issues (over decades) and do not represent short-term adjustments, whereas economic data are largely driven by short-scale processes. We claim, however, that this explanation is not satisfying, and this article will show that testing a longterm model on economic data perturbed by short-term mechanisms is possible and useful.

In this article, the response of the Indian economy to the rapid oil prices rise of the recent years will be investigated. India was chosen for this test because, in our model, India is highly vulnerable to oil shocks. For instance, for default parametrization of the model, India exhibits a 38\% decrease in growth rate for an 81\% increase in international oil price between 2003 and 2005, which is at odds with the observed resilience of the Indian economy to rising oil price over this period. Investigating why the modeled response of the Indian economy is not consitent with current observations will, therefore, be particularly useful to assess our model 
and give insights on the modeling methodology relevant to represent an economy's response to a shock.

We analyze the response of the Indian economy over the 2003-2006 period, because, over this period, economic data are available and no other large shock affected India. Before 2003, the Indian economy is still heavily affected by the consequences of the 2001 crisis in the U.S. After this period, macroeconomic aggregate estimates are not available yet.

In this paper, we have a twofold objective: on the one hand to disentangle the various types of mechanisms at play in India's economy response to rising oil prices and on the other hand to validate IMACLIM-R as a tool capable of reproducing short-run statistical data. Our methodology is the following. First, we compare the observed response of the Indian economy to the increase in oil world price and the response modeled with the standard calibration of our model. As shown in Section 2, there are very significant differences between the observed and modeled responses. In particular, the model predicts a much stronger decline in annual growth than what is observed. Second, we explore, in Section 3, whether the assumptions on labor productivity growth on which the model lies can be the source of this discrepancy, as labor productivity growth is the major growth driver together with population growth. We show that they cannot be the only explanation, except with implausibly high labor productivity growth. Third, we study in Section 4 alternative explanations for this discrepancy, from the February 2006 IMF country report on India (Fernandez, 2006): (1) the large capital inflow in India; (2) the incomplete pass-through of oil world price in the Indian market; (3) the rise of India as an exporter of refined products. We then include these mechanisms by changing the parametrization of the model and assess the ability of our modified model to reproduce the observed response of the Indian economy. In Section 5, we show how taking into account the three short-term mechanisms identified above modifies the model results, and allows the model to reproduce fairly well the recently observed response of India to rising oil prices. Section 6 concludes and proposes leads for future research. 


\section{Modeling macroeconomic response to oil shocks: a first modeling test}

Since the first oil shock in 1973, an abundant literature explored the relationship between energy prices and growth, on both the empirical side and the theoretical side ${ }^{1}$. On the empirical side, most of the analyses have focused on the U.S. and found that oil price shocks have affected output and inflation. In particular, Hamilton $(1983,1996)$ showed in a series of influential works that increases in the price of oil were followed by periods of recession in the US. On the theoretical side, considerable efforts were devoted to understand the nature and size of the interactions between the oil price and macroeconomic aggregates. There appears to be no consensus, and competing or complementary theories coexist ${ }^{2}$. Notably, Bernanke (1983) indicates oil price shocks lower value added because firms postpone their investments decisions while finding out whether the oil price increase is temporary or permanent, whereas Bruno and Sachs (1985) propose the "wage-price spiral" explanation: to prevent the real wage from falling, a decline in value added is necessary in response to an oil shock. Olson (1988) shows a potential channel of transmission is the transfer of wealth involved in paying higher oil import bills, and Hamilton (1988) suggests the recession is due to a shift in demand causing costly reallocation of labor accros sectors. Rotemberg and Woodford (1996) argue the decrease in output following oil price increase involves oligopolist behaviours of firms, whereas Finn (2000) imputes this decrease to variable capital utilization of firms under perfect competition. Bernanke, Gertler and Watson (1997) focus on the recessive effect of monetary tightening in response to the inflation risk.

The previous paragraph highlighted the theorical complexity of the interactions between oil prices and macroeconomic aggregates. Our interest in this paper is focused on how largescale models can draw on this complexity and represent the response to an oil price shock, which appears particularly difficult. On the one hand, Jones et al. (2004) assert that macromodels (IMF's MULTIMOD, OECD's INTERLINK, FRB's FRB/Global) are structurally unable to reproduce the magnitude of the economic response to oil price shock, as they resort to single-sector production functions and therefore do not capture the intersectoral resource (labor, capital, materials) reallocation costs. On the other hand, E3 CGE models represent

\footnotetext{
${ }^{1}$ See for example Jones and Leiby (1996) and Jones et al. (2004) for a detailed review of the literature.

${ }^{2}$ See for instance Barsky and Kilian (2004) for a review of the various channels through which oil prices may operate that were put forward.
} 
intersectoral interactions but Barker (2004) affirms that they are unsuited to model adjustment to price changes such as responses to oil price shocks because they are concerned with a set of equilibrium positions and do not represent transitional adjustment paths. Their limit, indeed, is to rest on modeling choices (full utilization of production factors, maximizing representative agents under perfect foresight, flexible production functions) that, most of the time, lead to instantaneous and frictionless readjustment to a new optimal growth path after perturbations. As a consequence, E3 CGE models represent long-term bifurcations but cannot capture short-term mechanisms.

IMACLIM-R architecture was developed to try and overcome the two shortcomings aforementioned (Crassous et al., 2006a, 2006b and Sassi et al., 2007). It is a hybrid model in two senses. (1) It is a hybrid model in the classical sense: its structure is designed to combine Bottom-Up information in a Top-Down consistent macroeconomic framework. Energy is explicitly represented in both money metric values and physical quantities so as to capture the specific role of energy sectors and their interaction with the rest of the economy. The existence of explicit physical variables allows indeed a rigorous incorporation of sector based information about how final demand and technical systems are transformed by economic incentives. (2) It is hybrid in the sense of Solow (2000) ${ }^{3}$, i.e. it tries and bridge the gap between long-run and short-run macroeconomics, as efforts were devoted not only to model long-term mechanisms but also focus on transition and disequilibrium pathways. We seek, indeed, to capture the transition costs with a modeling architecture that allows for endogenous disequilibrium generated by the inertia in adapting to new economic conditions due to both imperfect foresight and non flexible characteristics of equipment vintages available at each period (putty-clay technologies). The inertia inhibits an automatic and costless return to steady-state equilibrium after an exogenous shock. In the short run the main available flexibility lies in the rate of utilization of capacities, which may induce excess or shortage of production factors, unemployment and unequal profitability of capital across sectors.

Our model is calibrated on 2001 data from GTAP 5 database (Dimaranan and McDougall, 2002). Default parametrization comprise (i) exogenous trends for demography (UN World

\footnotetext{
${ }^{3}$ Solow (2000) : 'I can easily imagine that there is a « true » macrodynamics, valid at every time scale. But it is fearfully complicated [...] At the five-to-ten-year time scale, we have to piece things together as best we can, and look for a hybrid model that will do the job.'
} 
Population Prospects, medium scenario, UN, 2004) and for labor productivity growth (this point will be further developed in Section 3 of the article), (ii) resorption of international capital flows on the long term, (iii) Armington's specification (Armington, 1969) for nonenergy goods trade and a standard market-share equation depending on relative export prices for energy goods trade (so as to be able to sum physical quantities and track consistent energy balances).

To test our modeling architecture, we perform a first run of the model (simulation 1), with default assumptions for all exogenous parameters (in the following, referred to as the original version of the model). In this simulation, the oil price is fixed exogenously, to follow the observed oil price between 2001 and 2007 (see left panel of Fig. 1).
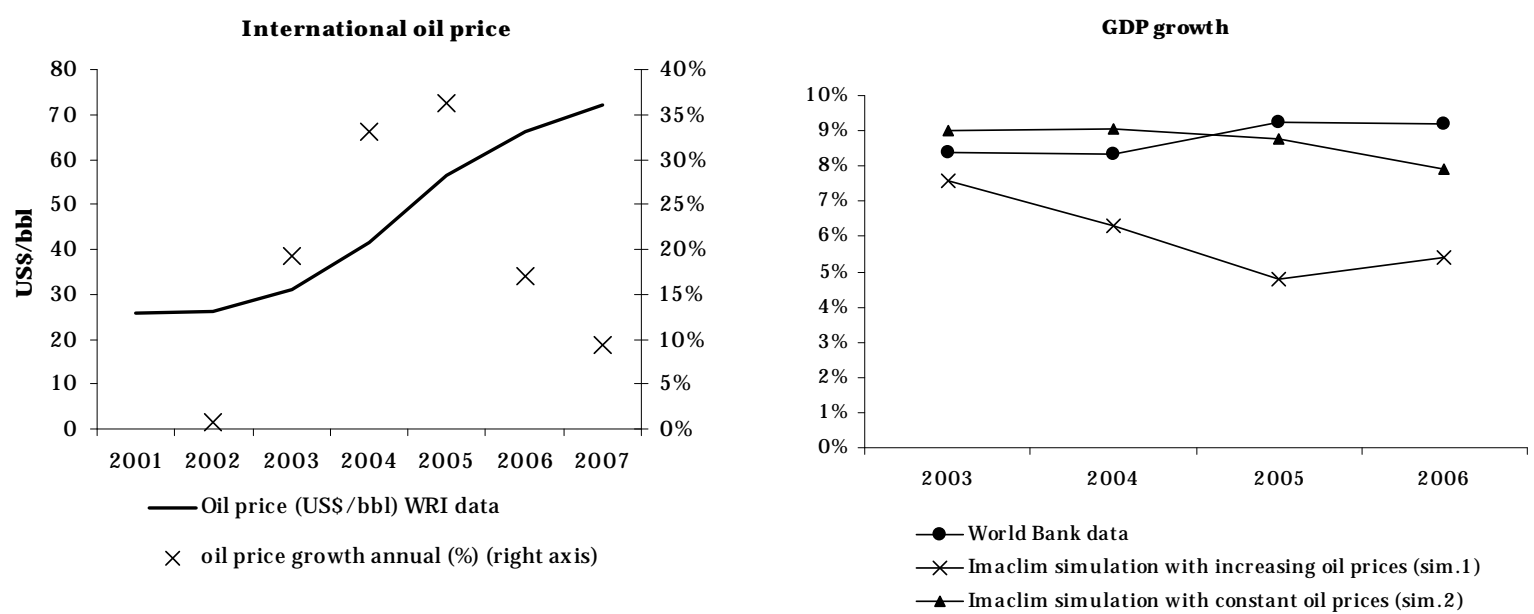

Figure 1: Left panel: International oil price observed during the 2001-2007 period.

Right panel: GDP growth computed by the model for simulation 1 with increasing oil prices (crosses) or simulation 2 with constant oil prices (triangles) or, and observed by the World Bank (points).

The right panel of this figure shows the Indian GDP growth in this simulation. With a rising oil price, the modeled GDP growth decrease from 7.6\% in 2003 to about $6.3 \%$ in 2004 and between 4.8\% and 5.4\% in 2005 and 2006, whereas, with constant oil prices (simulation 2), growth remains between $9 \%$ and $8 \%$ over this period. This figure shows clearly that, in the model, the Indian economy is highly vulnerable to variations of the international oil price. The model reveals an oil price-GDP elasticity equal to -0.048 , a median value compared to estimates summarized in Jones et al. (2004) ranging from -0.02 to -0.11 . But this result is at odds with recents observations in India: according to the World Bank, the Indian GDP growth lied between 8 and 10\% during this period, showing the robustness of the Indian economy. The model, therefore, does not reproduce observed facts. 
In the following, we will pursuit a twofold objective: first to try and explain why India's resilience to the rise of oil prices is not reproduced by our model; and second, to demonstrate whether our model results can approach observations, provided that additional mechanisms are included in the analysis. We will show that this exercise gives interesting insights on both the various mechanisms and policies at play in an economy's response to a shock and the modeling methodology appropriate to represent this response.

\section{Labor productivity gains as an explanation for India's resilience to the rise of oil prices?}

Our model growth engine is composed of exogenous demographic trends and technical progress that increases labor productivity, as in Solow's neoclassical model of economic growth (Solow, 1956). Demography simply follows UN scenarios but technical progress entails more uncertainty on the short-run. Solow's model (Solow, 1957) and following developments on growth accounting make technical change the residual of growth unexplained by demography or capital accumulation. Endogenous growth theories (see for instance Aghion and Howitt, 1992) explore the mechanisms at play behind technical change but the theoretical and empirical researches in this field are far too complex to be directly applied in models for long-term projections in the climate and energy domain. This is why we use exogenous trends of productivity growth, as it is a common practice in the energyenvironment modeling community. To build these trends we draw on stylized facts from the literature, in particular the convergence assumption (Barro and Sala-i-Martin, 1992) and two empirical analyses on economic convergence, one investigating the past trends by Maddison (1995), and the other one looking at future trends, by Oliveira Martins (2005). For India, default assumptions for labor productivity growth lie between 5.7\% and 5.3\% over the 20032006 period (Fig. 2).

The two sets of assumptions on demography and technical change, although exogenous, only prescribe potential growth. Effective growth results endogenously from the interaction of these driving forces with short-term constraints: (i) available capital flows for investments and (ii) not full utilization of production factors (labor and capital) due to the inadequacy between flexible relative prices (including wages) and inert capital vintages characteristics. 
As a consequence, the difference between our model's results and observations may arise from the growth engine or from the short-term constraints. We first try and reproduce the observed growth rate by modifying the growth engine. The demographic scenarios we use are adjusted on the short-term to follow actual demography statistics. Therefore, the uncertainty on the growth engine, over the short-term period we consider, lies mainly in the assumptions on technical change. Figure 2 shows the mean labor productivity growth assumptions that are necessary to make the model reproduce observed GDP growth (simulation 3). In these assumptions, labor productivity growth reaches a peak at 14\% in 2005.

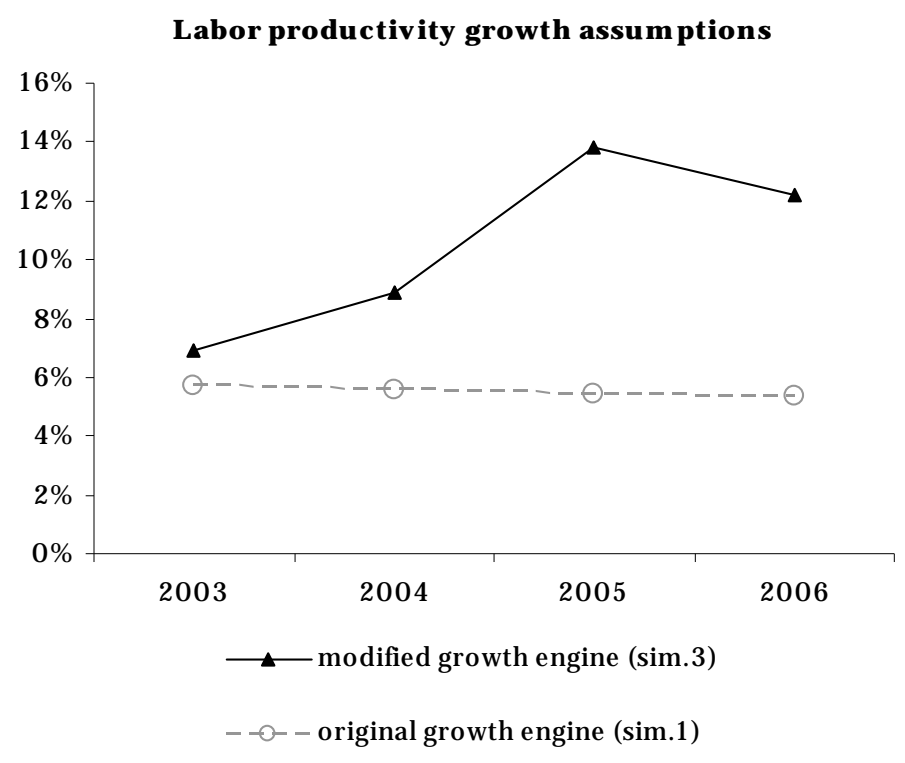

Figure 2: Mean labor productivity growth assumptions, for the original model (simulation 1) (grey dots) and for the modified (black triangles) growth engine, such that the model reproduces observed GDP over the 2003-2006 period (simulation 3).

These assumptions seem too high to be acceptable, in particular if checked against the limited set of data available on labor productivity in India (Bosworth and Collins, 2007) that give 3.1\% and 5.4\% labor productivity growth in the industry and services respectively on the period 1993-2004. We may also cite as an upper bound for plausible assumptions the labor productivity growth observed during economic take-off in Europe or Japan in the postwar period or in the Asian “dragons” (e.g. a peak at 9\% in France in $1969^{4}$, and $8.7 \%$ in South Korea in $1983^{5}$ ). Furthermore it seems unrealistic that the peak in labor productivity growth

\footnotetext{
${ }^{4}$ Source: INSEE. www.insee.fr.

${ }^{5}$ Source: OECD.Stat. http://stats.oecd.org/wbos/Index.aspx.
} 
takes place precisely the year when oil price growth is the highest, as labor productivity growth results in fact from economic activity dynamics.

As it is difficult to obtain reliable data on sectoral labor productivity growth, it is impossible to calibrate our model with real data on this point, but we may consider the original assumptions on labor productivity growth as more reasonable. In the following, we will therefore look for other mechanisms likely to explain the difference between the observed and modeled responses to the oil price rise, without resorting to accelerating the model growth engine.

\section{In search for other mechanisms}

The robustness of the Indian economy has been recently analyzed in a section of the February 2006 IMF country report on India (Fernandez, 2006). The report identifies four key mechanisms that explain the strong Indian growth despite rising oil prices:

(1) The sectoral reallocation of resources (away from oil-intensive activities) has been able to take place smoothly as the economy experiences rapid productivity gains;

(2) Large foreign currency reserves and strong capital inflows have limited the economy's need to adjust;

(3) The incomplete pass-through of international petroleum prices has moderated the income effect on domestic consumers;

(4) The rise of India as an exporter of refined products has moderated the impact of the terms of trade shock and the transfer of income abroad.

The first mechanism, refering to the structural change towards a lower importance of oil intensive activities and a greater importance of the service sector, is already present in our model. It is taken into account by the internal response of the model, which reproduces the sector interactions within the economic system. Figure 3 shows sectors contributions to the growth of added value, in the model results and according to World Bank data. It reveals that the model represents fairly well the sectoral structural change towards a greater importance of the service sector, which contributes to around $60 \%$ of the growth of total added value in both the model results and statistical data. The evolution of the TPES/GDP indicator, reduced by $3.2 \%$ over the $2003-2006$ period in the model's results and by $3.9 \%$ according to EIA data, 
also confirms that the model reproduces the aggregate effect of efficiency gains and structural change.

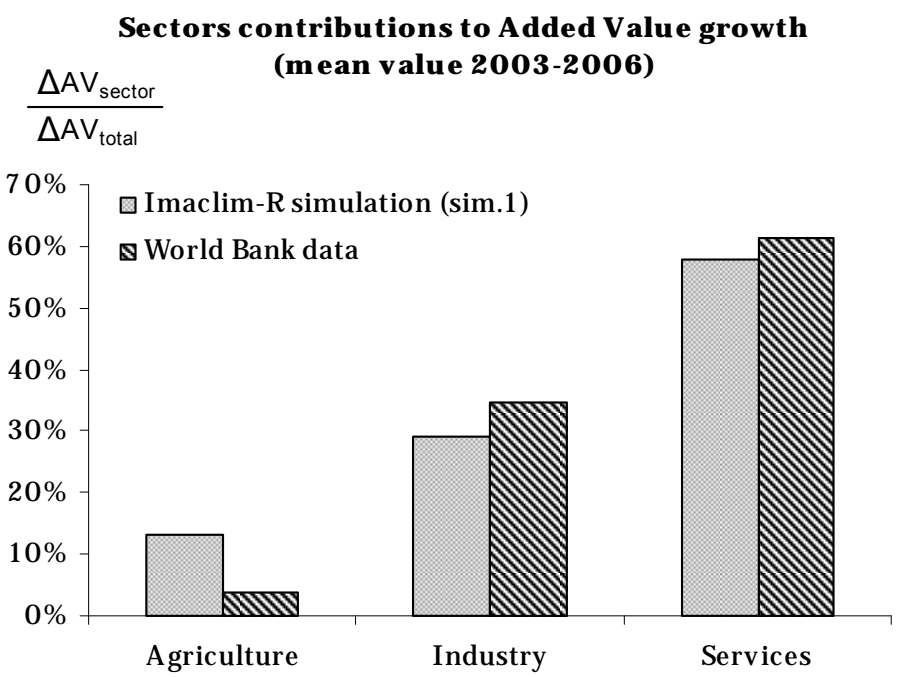

Figure 3: Sectors contribution to Added Value growth the 2003-2006 period, as modeled (results from simulation 1) and in the World Bank data ${ }^{6}$.

The last three mechanisms, on the opposite, are not taken into account by the model. First, as it is common practice in our field (e.g. Edmonds et al., 2004, Paltsev et al., 2005), the default assumption concerning capital flows in the model is that the trade balance and capital flows tend to zero over time in all countries, and that price levels adjust to maintain these trade and capital balances. This assumption results from the difficulty in predicting capital market and exchange rate dynamics, as country attractivity for investments ensues from many complex factors including political stability and corruption risk, and many others. Second, we assume in the original version of the model that the tax and subvention structure and the government budget structure are not modified in response to the rise in oil price. This assumption is made necessary by the high difficulty to predict, and all the more to model, the political response to an exogenous shock. These two shortcomings are acceptable in a long-term model because these imbalances can exist over the short-term but are not sustainable over the long-term: a government cannot increase its deficit or the country trade deficit for ever to compensate for increasing oil prices. Third, the endogenous formation of prices and export shares in the

\footnotetext{
${ }^{6}$ Part of the differences between modeled and observed sectors share lies in the fact the sectoral aggregation used in IMACLIM-R differ from the aggregation used in the World Bank database. For instance, food-processing industries are included in the agricultural sector in IMACLIM-R whereas it is counted in the industrial sector in the World Bank database.
} 
model does not reproduce the magnitude of the rise in Indian refined products exports: modeled export value of refined oil products evolves from 2.1 billion dollars in 2003 to 3.1 in 2006, whereas statistics show a rise to 6.1 billion dollars in 2006. This is due to the fact that the coefficients of the market-share equation representing energy goods trade are calibrated on 2001 data when India's exports of refined products represented a very small share of all traded refined products.

Since the model is tested against data that obviously include these mechanisms, these additional mechanisms need to be taken into account by the model in this validation exercise. In the following, we will exogenously introduce these mechanisms in our modeling exercises.

\section{Further modeling exercises.}

To see if the model is able to reproduce the observation, the three missing explaining factors identified in the previous section have been introduced in the model. It is out of the scope of this paper to model the full complexity of these mechanisms. To take them into account, therefore, we modified the parametrization of some elements in the model so as to approximate the aforementioned mechanisms.

First, to model the effect of the strong capital inflows into India and the large foreign currency reserves of this country, we forced the imports of capital into India, from all other countries, so that the Indian trade balance fits to the statistical data (simulation 4), whereas in the initial version of the model the country imports of capital remain a constant share of all international capital flows (see Figure 4). 


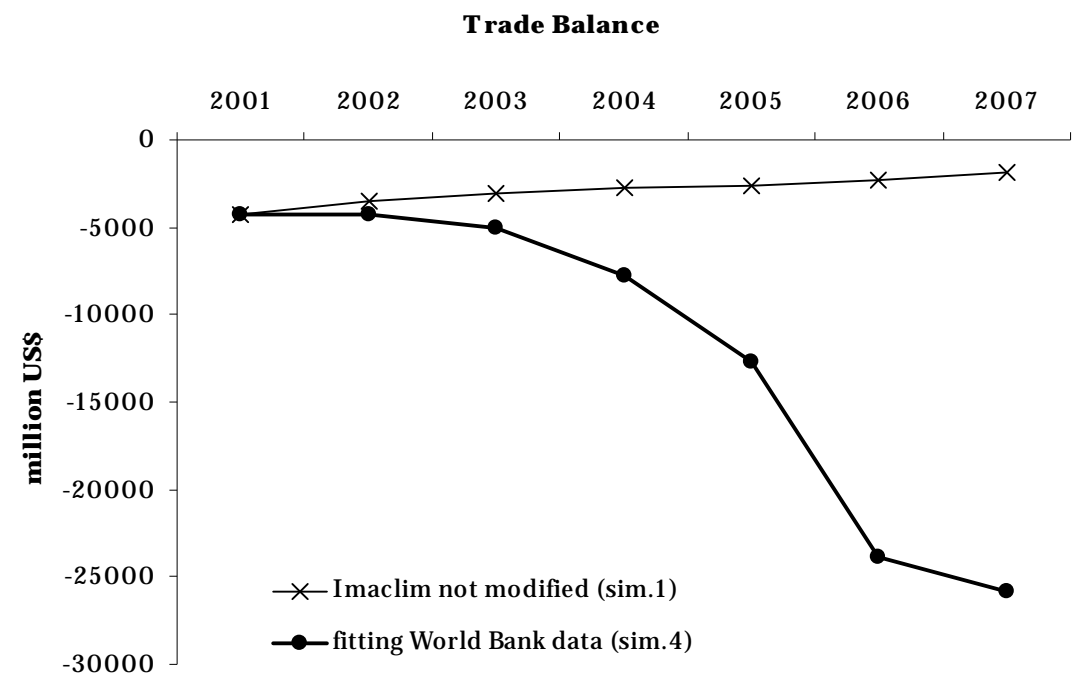

Figure 4: Indian trade balance between 2001 and 2007, as modeled by the original version of the model (crosses) and as observed by the World Bank (points). In the modified model version, the trade balance is forced to follow the observations (simulation 4).

Second, to represent the incomplete pass-through of international petroleum prices to domestic consumers, we introduced a government subsidy to oil products consumption that takes the form of tax reductions (simulation 5). Alternatively, we could have chosen to channel the subsidy through cuts in the government-owned petroleum company margins, which would have given similar results as more than $95 \%$ of petroleum products consumed are domestically refined. The resulting fiscal deficit is financed by a fraction of the foreign capital inflow, which can be seen as an increase of the government foreign debt (even if debt mechanisms are not explicitly modeled in the current version of the model). According to data from the IMF country report, we represent a $40 \%$ pass-through, i.e. the fact that domestic oil price increased only by $40 \%$ of the rise in international oil price.

Finally, the rise of India as an exporter of refined products is reproduced by forcing exogenously the volume of refined-product exports to follow the data (simulation 6), while the original model calculates it endogenously from the interplay between supply, demand and relative prices.

Figure 5 shows the results of the initial model (simulation 1) and of several model versions, including one (simulations 4, 5 and 6), or all of these three additional short-term mechanisms (simulation 7). It shows that, while the original model simulates a strong decline in GDP 
growth, the modified model version that includes the three additional mechanisms is close to observations. Our results, therefore, confirm that the three aforementioned mechanisms are able to explain why the Indian GDP growth remained at a high level in the 2003-2006 period despite rising oil prices.

\section{GDP growth}

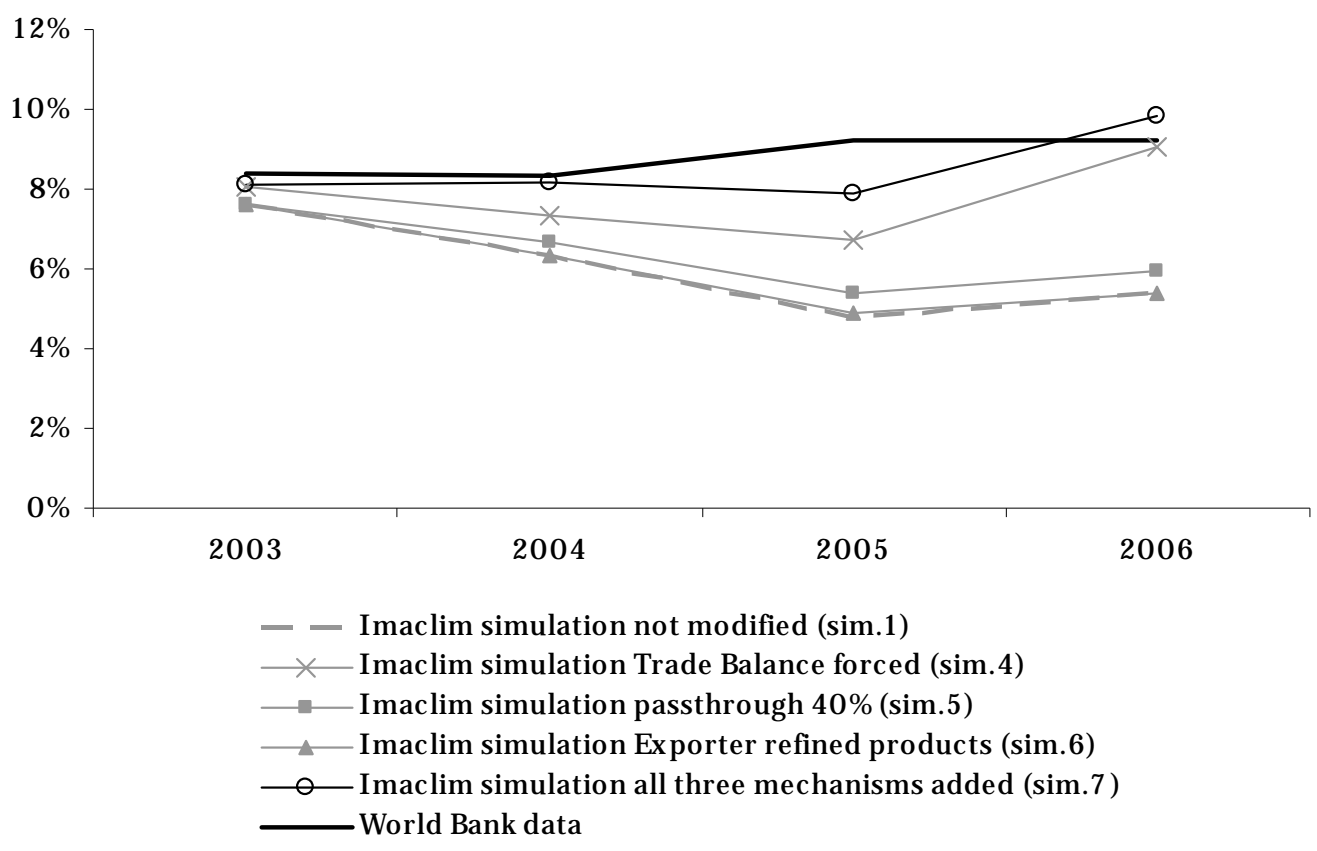

Figure 5: Observed GDP growth in India between 2003 and 2006, and results of the initial model version (simulation 1) and of several modified model versions, including one (simulations 4, 5 and 6) or all additional short-term mechanisms (simulation 7).

Adding the three factors one by one allows one to discriminate their respective contribution in narrowing the gap between the model initial results and the data. In our model at least, the dominating effect is the disequilibrium of the trade balance that is permitted by strong capital inflows. This mechanism alone increases GDP growth by more than $2 \%$ in 2005 . As a comparison, the partial pass-through alone is only able to increase growth by less than $1 \%$, and the rise in exports can hardly be distinguished from the baseline produced by the original model.

The simulation in which the three mechanisms are included gives growth rates relatively close to statistical data. Indeed, for 2005, the year for which the difference is the largest, the model gives a $7.9 \%$ annual growth rate instead of the observed 9.2\%. These results show how short-term flexibility, here through changes in trade balance and capital flows in particular, can influence in a significant manner short-term GDP growth, and smooth exogenous shocks. 
As an additional test of our modified model version, we compare in Figure 6, the evolution of the sectors shares in added value given by the model and observed. These results show that the model does not only reproduce aggregate growth, but is also able to capture fairly well its sectoral distribution ${ }^{7}$.

Sectors shares in Added Value in 2003

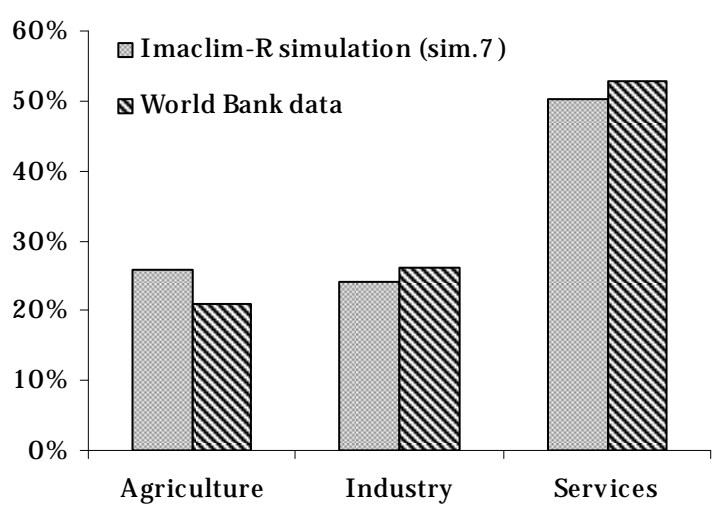

Annual growth of sectors shares in added value

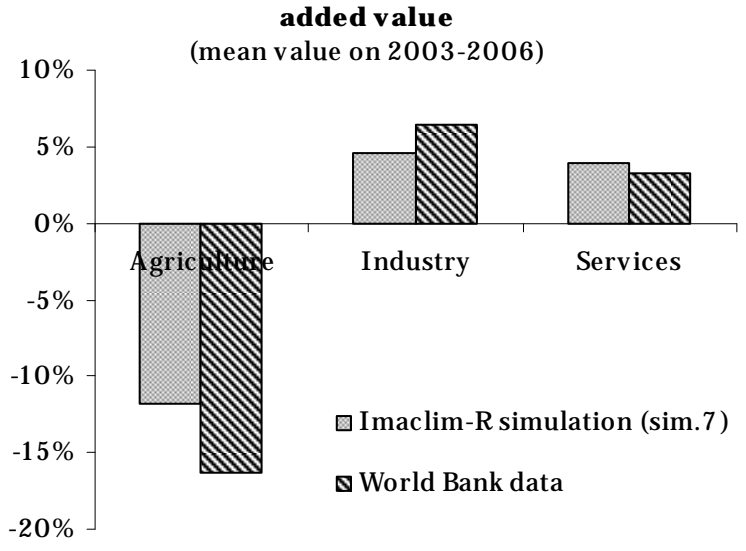

Figure 6: Sectors shares in Added Value in 2003 and their mean annual growth rate over the 2003-2006 period, as modeled (results from simulation 7) and in the World Bank data ${ }^{6}$.

Of course, our results are not perfect and there is still a difference between our model results and the observed response of the Indian economy. Section 2 showed that changes in productivity growth alone could not explain the resilience of the Indian economy. They may, however, explain the small remaining difference between the modeled and observed economy. We may now look for the appropriate labor productivity growth assumptions (simulation 8) that should be introduced in the modified model to bridge the remaining gap between modeled and observed GDP (Fig. 7). They appear to remain in a plausible interval, as they peak at $8 \%$.

\footnotetext{
${ }^{7}$ The additional mechanisms included in the model influence aggregate growth, but do not change in a significant manner the sectoral distribution of growth.
} 


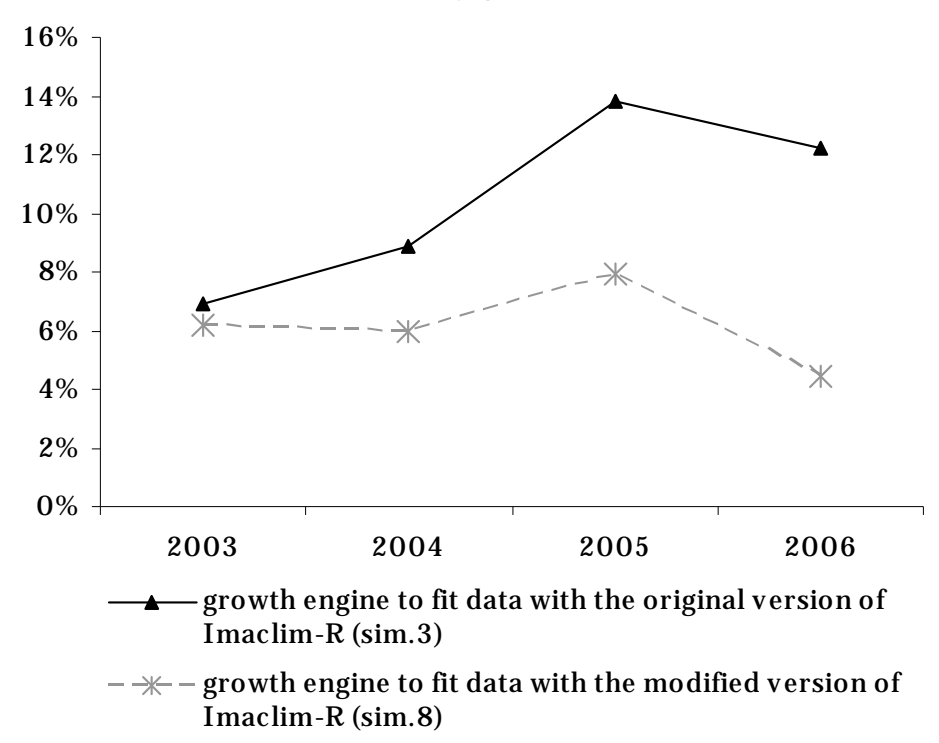

Figure 7: Mean labor productivity growth assumptions to fit GDP data with the original version of the model (simulation 3) (black triangles) and with the modified version of the model (simulation 8) (grey crosses).

We may also suggest that this difference is partly due to other economic mechanisms that are imperfectly reproduced by our model, such as the response of the informal economy, or the response of the monetary policy, as explored notably in Blanchard and Gali (2007). These mechanisms are important and require additional research to be included in a global energyeconomy model.

\section{Conclusion}

This paper is a first step toward a validation of our long-term global energy-environmenteconomy CGE model against macroeconomic data. In its original version, indeed, the model is not able to reproduce the observed Indian GDP growth rate, and it overestimates the consequence of a rise in oil price on the economy. Taking into account three mechanisms identified in the IMF country report and disregarded in the original model modifies significantly the model results, and allows the model to reproduce fairly well the observed economic data. In particular, these results stress the importance of the modeling of capital flows, which is a weak point in current models. Our results also have policy implications as they highlight two mechanisms that smooth the adverse effect of oil shocks over the short term, and on which the policy makers have partial control (the subsidy to oil products 
consumption and the capital inflow or trade balance deficit). Moreover, the respective effect of both mechanisms is assessed, indicating that the most powerful lever lies in the disequilibrium of the trade balance that is permitted by strong capital inflows.

In terms of model validation, this paper remains partial, since it considers only a single country, in a single period, and a single type of shock. It is needed, therefore, to conduct similar tests for other countries or regions and other periods to further assess our model; and with other models to discriminate among the various modeling choices that are made in our research community.

From a methodological point of view, our results suggest that the inability of the model to reproduce historical data arise from short-term mechanisms that are explicitly disregarded. It appears, additionally, that the mechanisms that are needed to reproduce the observed Indian response to the rise in oil price are bound to remain short-term or local mechanisms. It seems unrealistic, indeed, that the trade balance deficits keep growing for decades in all world energy-importing countries. Also, government subsidies cannot keep offsetting price increases on the long run. Therefore, it appears acceptable not to embark these mechanisms in our modeling architecture when analyzing long-term and global evolutions. But these shortterm mechanisms might, however, play a major role in the transition dynamics, either to smooth negative impacts of energy price shocks or carbon tax - like in the Indian case - or to amplify negative impacts if a short-term process acts as an amplifying feedback. This is of particular importance for our modeling work. Indeed, following the intuition that climate change mitigation costs are mainly transition costs, IMACLIM-R architecture was specifically designed to explore transition pathways. Important efforts were expended to represent the inertia (e.g., technical and infrastructure inertia) responsible for transition costs and to model trajectories year by year. But this paper indicates further efforts should be devoted now to explore how short-term mechanisms, such as the temporary deficit of the trade balance, may play a role in the transition to a low-carbon economy and allow to smooth adverse effects of shocks.

Additionally, disregarding short-term mechanisms means assuming a complete separation between short-term and long-term dynamics. This assumption is at the heart of the growth theory but has been questioned by several authors (e.g., Solow, 1988; Arrow, 1989). We may thus conclude on another prospect for future research. It is necessary to investigate how short- 
term mechanisms might influence long-term growth pathways (see an attempt to do so in Hallegatte et al., 2008) or, in other words, if there is a path-dependency of long-run growth. If this influence is non-negligible, indeed, the analysis of short-run mechanisms will have an undeniable place in the understanding of long-run macroeconomy, and modeling teams will have to devote more time to the apprehension of the links between short-term dynamics and long-term trajectories.

\section{Acknowledgments}

The authors wish to thank Olivier Sassi, Jean-Charles Hourcade and Philippe Quirion for their useful comments and suggestions, as well as Henri Waisman, Meriem Hamdi-Cherif, Sandrine Mathy and all the team who contributed to IMACLIM-R development.

\section{References}

Aghion, P., Howitt, P., 1992. Endogenous Growth Theory. MIT Press, Cambridge.

Armington, P. S., 1969. A Theory of demand for products distinguished by place of production. IMF, International Monetary Fund Staff Papers 16, 170-201.

Arrow, K., 1989. Workshop on the economy as an evolving complex system: summary. In: Anderson, P., Arrow, K., Pines, D. (Eds.), The Economy as an Evolving Complex System. Addison-Wesley, New York, pp. 275-282.

Barker, T., 2004. The transition to sustainability: a comparison of General-Equilibrium and Space-Time-Economics approaches. Tyndall Centre Working Paper, vol. 62. Tyndall Centre for Climate Change Research, University of East Anglia, Norwich.

Barro, R. J., Sala-i-Martin, X., 1992. Convergence. Journal of Political Economy 100:2, 223251. 
Barsky, R.B., Kilian, L., 2004. Oil and the Macroeconomy since the 1970s. Journal of Economic Perspectives 18:4, 115-134.

Bataille, C., Jaccard, M., Nyboer, J. and Rivers, N., 2006. Towards general equilibrium in a technology-rich model with empirically estimated behavioral parameters. The Energy Journal, Special Issue 2.

Bernanke, B.S., 1983. Irreversibility, uncertainty, and cyclical investment. Quarterly Jounral of Economics 98:1, 85-106.

Bernanke, B.S., Gertler, M., and Watson, M.W., 1997. Systematic monetary policy and the effects of oil price shocks. Brookings Papers on Economic Activity 1, 91-148.

Blanchard, O.J., Gali, J., 2007. The Macroeconomic effects of oil price shocks: Why are the 2000s so different from the 1970s? International Dimensions of Monetary Policy, University of Chicago Press (forthcoming).

Bosetti, Valentina, Carlo Carraro, Marzio Galeotti, Emanuele Massetti, and Massimo Tavoni. (2006). WITCH: A World Induced Technical Change Hybrid model. The Energy Journal, Special Issue 2.

Bosworth, B., Collins, S.M., 2007. Accounting for growth: Comparing China and India. NBER Working Paper 12943.

Bruno, M., and Sachs, J.D., 1985. Economics of worldwide stagflation. Cambridge, Harvard University Press.

Crassous, R., Hourcade, J.-C., Sassi, O., 2006a. Endogenous structural change and climate targets: modeling experiments with Imaclim-R. Energy Journal, Special Issue on the Innovation Modeling Comparison Project.

Crassous, R., Hourcade, J.-C., Sassi, O., Gitz, V., Mathy, S., Hamdi-Cherif, M., 2006b. IMACLIM-R: a modeling framework for sustainable development issues. Background paper for 
Dancing with Giants: China, India, and the Global Economy. Institute for Policy Studies and the World Bank, Washington, DC. Available at http://siteresources.worldbank.org/INTCHIINDGLOECO/Resources/IMACLIM$\underline{\text { R_description.pdf. }}$

Dimaranan, B.V., McDougall, R.A., 2002. Global Trade, Assistance, and Production: The GTAP 5 Data Base. Center for Global Trade Analysis, Purdue University.

Edenhofer, O., Lessmann, K., Bauer, N., 2006. Mitigation strategies and costs of climate protection: The Effects of ETC in the hybrid model MIND. Energy Journal, Special Issue on Endogenous Technological Change and the Economics of Atmospheric Stabilisation.

Edmonds, J., Pitcher, H., Sands, R., 2004. Second General Model 2004: An Overview.

Finn, M.G., 2000. Perfect competition and the effects of energy price increases on economic activity. Journal of Money, Credit and Banking 32:3, 400-416.

Hallegatte, S., Ghil, M., Dumas, P., Hourcade, J.-C., 2008. Business cycles, bifurcations and chaos in a neo-classical model with investment dynamics. Journal of Economic Behavior \& Organization 67, 57-77.

Hamilton, J., 1983. Oil and the Macroeconomy since World War II. Journal of Political Economy 91:2, 228-248.

Hamilton, J., 1988. A neoclassical model of unemployment and the business cycle. Journal of Political Economy 96:3, 593-617.

Hamilton, J., 1996. This is what happened to the oil price macroeconomy relationship. Journal of Monetary Economics 38:2, 215-220.

Hourcade, J.-C., Jaccard, M., Bataille, C., Ghersi, F., 2006. Hybrid modeling: New answers to old challenges. The Energy Journal, Special Issue 2, 1-11. 
Fernandez, E., 2006. Dealing with higher oil price in India. In: International Monetary Fund, 2006. India: Selected Issues. IMF country Report 06/56.

Jones, D.W., Leiby, P.N., 1996. The Macroeconomic impacts of oil price shocks: A Review of literature and issues. Oak Ridge National Laboratory.

Jones, D.W., Leiby, P.N., Paik, I.K., 2004. Oil price shocks and the macroeconomy: What has been learned since 1996. The Energy Journal 25:2.

Maddison, A., 1995. Monitoring the world economy: 1820 - 1992. OECD Development Center.

McKitrick, R., 1998. The econometric critique of computable general equilibrium modelling: the role of functional forms. Economic Modelling 15:4, 543-573.

Oliveira Martins, J., Gonand, F., Antolin, P., de la Maisonneuve, C., Kwang, Y., 2005. The impact of ageing on demand, factor markets and growth. OECD Economics Department Working Papers 420.

Olson, M., 1988. The productivity slowdown, the oil shocks and the real cycle. Journal of Economic Perspectives 2:4, 43-69.

Paltsev, S., Reilly, J.M., Jacoby, H.D., Eckaus, R.S., McFarland, J., Sarofim, M., Asadoorian, M., Babiker, M., 2005. The MIT Emissions Prediction and Policy Analysis (EPPA) Model: Version 4. MIT Joint Program Report 125.

Rotemberg, J., Woodford, M., 1996. Imperfect competition and the effects of energy price increases on economic activity. Journal of Money, Credit and Banking 28:4, 549-577.

Sassi O., Crassous, R., Hourcade, J.-C., Gitz, V., Waisman H., Guivarch, C., 2007. Imaclim-R: a modelling framework to simulate sustainable development pathways. International Journal of Global Environmental Issues (accepted). 
Schäfer, A., and Jacoby, H.D., 2006. Experiments with a Hybrid CGE-MARKAL Model. The Energy Journal, Special Issue 2.

Scrieciu, S., 2007. The inherent dangers of using computable general equilibrium models as a single integrated modelling framework for sustainability impact assessment. A critical note on Böhringer and Löschel (2006). Ecological Economics 60, 678-684.

Solow, R., 1956. A Contribution to the Theory of Economic Growth. Quarterly Journal of Economics 70:1, 65-94.

Solow, R., 1957. Technical change and the aggregate production function. Review of Economics and Statistics 39, 312-320.

Solow, R., 2000. Toward a macroeconomics of the medium run. Journal of Economic Perspectives 14:1, 151-158.

UN, 2004. World Population Prospects: the 2004 revision. 